\title{
Decent and coarse forms of political economy: Evidence from South Africa
}

\begin{abstract}
Aregbeshola R. A
Department of Business Management, College of Economic and Management Sciences, University of South Africa, Preller Street, Muckleneuk Ridge, City of Tshwane, South Africa. E-mail: aregbra@unisa.ac.zaTel: +27 124298505.

Accepted 27 May, 2011

The Political economy of a country is influenced by the economic philosophy and political ideology of the leadership. Evidence suggests a positive relationship between a country's economic development and the macroeconomic environment. For instance, the impact of macroeconomic policies adopted upon political emancipation in South Africa has been questionable. With a neoliberal undertone, the policy's prevision to attract long-term foreign capital, which was expected to drive economic growth and generate employment, has proven to be over-ambitious. Research was done on the perception of the policymakers and investors on the effectiveness of the policy initiatives on capital inflow and socioeconomic variables. Using descriptive statistics, the research suggests that the current policies need to be reformed to achieve socio-economic peacefulness, which is essential to creating an investor-friendly environment. Increasing social unrest in the country makes it vital to formulate policies that are capable of improving the country's investment competitiveness. If unchanged, the current socio-economic ills that have generated a series of uprisings may become unmanageable, thereby precipitating political instability.
\end{abstract}

Key words: Policy regimes, macroeconomic policies, the RDP and GEAR, FDI in South Africa.

\section{INTRODUCTION}

The macroeconomic policies adopted by the ANC-led Government of National Unity (GNU) upon political emancipation have been self-defeating. While the strategic rationale of these policies was progressive in nature, their practical implication has been dispiriting. These macroeconomic policies, essentially the Growth, Employment and Redistribution (GEAR) strategy, has been criticised for the socio-economic difficulties that have befallen the country since 1994 (Fine, 1995; Magubane, 2002). Evidence suggests that the controversy generated by this policy has resulted in the polarisation of its acceptance across opinion divides (Michie and Padayachee, 1998; Lewis, Reed and Teljeur, 2004). While the GEAR policy is popular among the business community (essentially local investors), it is largely unpopular among foreign investors, as well as the less privileged populace. The twin-aisle of the policy has exacerbated the reality of The 'two-economies' that characterise the country

JEL classification: E2, E24, H3, H5.
(Adelzadeh, 1996; Alda and Cuesta, 2010). While business views government policies, including the Reconstruction and Development Programme (RDP) as being favourable to investment, the public are sceptical of the alleged trade-off between government's social responsibility and its pursuit of global capital, which these macroeconomic policies facilitate (Alda and Cuesta, 2010)The enervation thesis is premised on various findings, all of which suggest that capitalism is widely criticised for being primarily interested in taking advan-tage of the less privileged people and their situations (Rich, 1994; Kapstein, 1999; Philips, 2000; Smith and Moran, 2000; Stiglitz, 2002; Wallach and Woodall, 2004).

The shortfalls inherent in these policies in respect of poverty alleviation have resulted in social unrest, which has further unsettled the skittish foreign investors. Unemployment rates have risen from about 22\% in 1994 to almost $40 \%$ in 2008 (Statistics SA, 2009) - a trend that has been furthered by the twin-aisles of global financial crises and global economic recession of 2008/09. Although South Africa's economic performance 
has been steady since 1994, the innate deficiencies of these policies on the socio-economic dimensions have over-shadowed this achievement (Weeks, 1999; Wessel, 2007). The enabling environment needed to attract foreign investment has been fouled by incidences of violent protests, escalating aggravated crime and increasing unemployment in response to the academic scheme of these policies (Nattrass, 2001; Roberts and Thoburn, 2004; Wessel, 2007). Even though, the envisaged stable fiscal and monetary targets have materialised, it has been at the expense of foreign direct investment (FDI) inflow into the country, which was targeted as growth catalyst and employment accelerator.

While these macroeconomic policies were intended to attract inflow of FDI, they have - ironically - led to quite a number of divestments. Given the volatility created by the policies, inflow of foreign capital has largely been dominated by portfolio investment, which is less growthstimulating than FDI (UNCTAD, 2008). Since some of the alliance partners of the ruling elites regard the current socio-economic situation in the country as being potentially risky, efforts are required to address the inherent lapses in these policies in order to achieve their desired goal: socio-economic peacefulness that is capable of attracting growth-induced FDI inflows.

This article focuses on the impact of policy initiatives by the South African government regarding the attractiveness of the country to FDI inflows since 1994. The basic measurable indicators of RDP and GEAR as macroeconomic policies are reviewed and the general implication of these policies, as well as the divergence of their acceptability, is re-examined.

\section{Background information on RDP and GEAR}

To resolve trade imbalances and related economic problems that characterised the apartheid regime, the Government of National Unity (GNU) adopted a Keynesian economic approach (expanded public spending on social and infrastructural facilities), called the Reconstruction and Development Programme (RDP). The policy encapsulated 'six cardinal points': 'An integrated programme, based on the needs of people; that provides peace and security for all and builds the nation, links reconstruction and development and deepens democracy' (RDP 1994, section 1.3.8).

Prior to political emancipation in 1994, the South African GNU convened the Macroeconomic Research Group (MERG) to charter a way forward to achieving economic recovery from the quandary that characterised the apartheid regime. MERG was charged with the responsibility of designing an economic policy suitable to address the plethora of apartheid irregularities that had impacted negatively on the economy. Using MERG's recommendations as an arsenal, the GNU adopted the RDP as a macroeconomic strategy. The programme, at constituencies of the GNU as well as those of other affected stakeholders, such as the trade unions. Despite the conviction that this programme would serve as the ultimate 'redistribution' loadstar, the document failed to provide for some crucial policy directives, especially the industrial strategy (Standing, Sender and Weeks, 1996; Michie and Padayachee, 1998), which contributed to its vulnerability. The support generated by the RDP portrayed it as an appropriate antidote to the legacies of apartheid. The programme was presented as a product of consultation and extensive debate, thereby spawning widespread support for it as a 'coherent and viable' initiative.

Many proposals, strategies and policy initiatives combined to form the RDP policy framework. These are grouped into five major categories (RDP, 1994 section 1.1.4), namely:

1. Meeting basic needs;

2. Developing human resources;

3. Building the economy;

4. Democratising the state and society, and

5. Implementing the RDP.

The government identified the basic needs of the people as job creation, land security, housing, water, electricity, telecommunications, transport, a clean and healthy environment, nutrition, healthcare, and social welfare (RDP, 1994:7). To meet these needs the government established 'achievable' programmes over a five-year period. These included land redistribution to the landless people, the building of over one million houses for the less privileged, provision of a clean environment for all, electrifying 2.5 million new homes, and the provision of accessible/affordable healthcare and telecommunications (RDP, 1994 sections 1.3.2-1.3.8).

These programmes were meant to address poverty and social deprivation prevalent mostly amongst the rural dwellers (at the time, an estimated 17 million people were surviving below the Minimum Living Level at that time and more than 11 million lived in rural areas), as a way of leveraging crime rate - a measure designed to achieve a sustainable investor-friendly environment. ${ }^{1}$

The shortfalls of the RDP emanated from the government's inability to generate needed resources to finance the programme, ${ }^{2}$ coupled with its failure to establish an industrial policy. Also, the lack of compatibility between the political ideology of the ANC-led alliance, and the adopted economic orthodoxy - mainly trade liberalisation and privatisation (Hirsch, 1993; Nattrass, 1994) - further incapacitated the policy. Fine (1995: 21) was more critical of the proposed privatisation measure, as he observes

\footnotetext{
${ }^{1}$ This assumption has been proven valid by the 2010 statistics, as crimes that are more violent are committed in the rural areas or in the urban areas by migrants from the rural areas.

${ }^{2}$ The government resolved to finance RDP through privatisation, a decision that was not well received by some critics (Fine, 1995:17; Michie and Padayachee, 1998:624).
} 
whatever the motives or reasoning underlying the privatisation programmes were, they are seriously deficient in in logic and ethos. This is because; privatisation does not offer the means of realising the RDP but rather, merely represents its erosion and redefinition. Privatisation was considered an anti-thesis-consolidation of, and continuity with, the economic powers and policies of the past regime" - the apartheid (my emphasis).

The inadequacy of the programme manifested in the abandonment of interventions in support of rural development and social security issues, because the interest of capital became more central (Weeks, 1999). The strategy was savaged by the financial crises that hit South Africa in 1996, which resulted in capital flight and economic instability, necessitating a national call by $\mathrm{Mr}$ Mandela (the then President) for the 'public and private sectors to develop and implement a national vision' (Nattrass, 1996:25). This Presidential call generated spontaneous response from various quarters of the economy, such as the National Economic Development and Labour Council (NEDLAC), the South African Labour Movement (SALM), the International Labour Organisation (ILO) and the South African Foundation (SAF). Within a few weeks SAF, a consortium of 50 top South African companies, responded with a presentation of 'Growth for All'. This was followed by SALM's 'Social Equity and Job Creation'. The ILO country review of South Africa supported the SALM proposition. The government blocked this development in June of the same year when the then Finance Minister, Trevor Manuel, presented the GEAR macroeconomic framework (Nattrass, 1996; Michie \& Padayachee, 1998).

These policy proposals were not only diverse in origin but also in content and acceptability. While the SAF's blueprint advocated a free-market economy, SALM proposed legislative interventions to establish labour standards, collective bargaining, and a boost to the supply-side of the economy. GEAR, on the other hand, threw its weight behind the government's orthodox macroeconomic policy, which stressed deficit reduction and a tight monetary policy, combined with trade liberalisation (Weeks, 1999). According to Mr Manuel, the GEAR policy framework was devised as an instrument for building and restructuring the economy by addressing the failings of the RDP. He further contended that the GEAR was designed as an integrated economic strategy capable of expiating challenges that subjugated the achievements of the RDP, like meeting basic needs, developing human resources, increasing participation in the democratic institutions of civil society and implementing the RDP in all its facets (GEAR, 1996). The ensuing empirical interrogation alludes to the paucity of some of the tenets of GEAR as a macroeconomic policy. This Neo-liberal approach - embedded in GEAR appears to negate the provisions of the ANC's earlier Keynesian paradigm that sought a leading and enabling role for government in guiding the mixed economy through a process of reconstruction and development.
The policy proposes a living wage, as a prerequisite for achieving the required level of economic growth and development, and a sustainable investment-friendly environment capable of attracting FDI (GEAR, 1996).

\section{The GEAR and FDI inflow}

GEAR was adopted by the Government on the premise that the policy framework would create the needed enabling environment to facilitate FDI inflow - a perceived sine qua non for economic growth and poverty alleviation. However, this has proven to be elusive (Standing, Sender and Weeks, 1996; Weeks, 1999). To evaluate the impact of GEAR on FDI inflow, it is necessary to probe the veer of the policy's measurable indicators. Those indicators include the reduction of the fiscal deficit relative to the gross domestic product (GDP), the reduction of inflation/interest rate adjustments, employment creation, poverty alleviation and wealth redistribution, and trade liberalisation - all of which are aimed at creating an investor-friendly environment.

The summary of GEAR as a policy framework provides macroeconomic guidelines, some of which match the recommendations of the apartheid state as contained in the Normative Economic Model (NEM). The Normative Economic Model (NEM), the SAF, the World Trade Organisation (WTO) and the International Financial Institutions (IFIs) - the International Monetary Fund (IMF) and the World Bank (WB) - all supported trade liberalisation and economic openness (Nattrass, 2001).

On an assumption of spontaneous inflow of foreign capital, the policy projected that about $93 \%$ of the total stimulus expected to achieve the targeted GDP growth (4.2\% between 1996 and 2000) would be generated by private investors (Weeks, 1999). By implication, the success of GEAR principally depends on the immediate success of the government to stimulate private (foreign) investment (Adelzadeh, 1996). In essence, the success of GEAR was contingent on volatile foreign capital inflows (Michie and Padayachee, 1998; Fine and Rustomjee, 1996; Gilroy, Gries and Naude, 2005). Amongst others, the policy canvassed certain attitudes and measures that conform to the dictates of economic orthodoxy, which are observed to be inconsistent with a desire (inter alia) to alleviate poverty and enlarge the local market capacity while creating an enabling environment capable of attracting FDI inflow (Nattrass, 2001; Gelb, 2006). Some of these attitudes and measures are discussed below:

\section{Concern for inflation/the use of interest rate}

The GEAR policy is orchestrated on the premise of inflation targeting. The Reserve Bank Act 90 of 1989 provides that the primary goal of the Bank is the protection of the domestic and external value of the Rand'. The enabling Act grants the Bank certain measures of independence in designing appropriate policies 
to fight inflation and to protect official foreign reserves. These briefs are engineered to ensure the maintenance of monetary stability. It does this by formulating and implementing effective fiscal and monetary stabilisation policies in the economy (Schimulow and Greyling, 1996). The most powerful instrument used by the Bank in this regard appears to centre on interest rates. The Bank raises interest rates to reduce the demand for loans, curb total domestic expenditure, and thus reduce the amount of money in circulation (Frank, 1969). The level of interest rate (either high or low) determines the growth potential of consumer spending and subsequently, economic productivity (De Vroey, 1984; Javier and Ignacio, 1997).

Over time, the Bank has been successful in achieving a moderate inflation rate. Resting on its laurel, inflation targeting appears to be anti-poor as it places a restraint on government spending (Weeks, 1999; Adelzadeh, 1996). Although inflation affects the poor the most and can lead to lower productivity, judging from the experience of many countries it is to be doubted whether inflation hinders growth or if low levels of inflation are a prerequisite for growth (MERG, 1993). Indeed, low or moderate inflation have a temporarily negative impact on growth, leading to significant and permanent reductions in per capita income (Barro, 1995, 1996; De Gregorio, 1996). In the South African context, reducing moderate levels of inflation has culminated in enervating unemployment, thereby forestalling poverty alleviation (Nattrass, 2001).Interest rates were raised consecutively for the tenth time on 12 June 2008 as a measure to cushion the cy-clical effects of inflation on the economy. Consequently, the rate of unemployment in the country increased. Formal employment has continued to decline due to slow economic growth occasioned, inter alia, by the high interest rates. Specifically, the overall unemployment figure for the country was quoted at 41.8\% in October 2007 (Business Anti-corruption, 2007). Unemployment continues to increase across racial lines in the country - the same source puts it at 5\% among the white popu-lation, $20 \%$ among Indians and the coloured population, and more than $36.8 \%$ among the black population. It is evident that GEAR's policy stance on inflation has resulted in more unemployment rather than in creating jobs (Nattrass, 2001). Arguably, many factors (like global economic swings) might have contributed to the performance of the economy during these periods. However, there is a prima facie case that the GEAR policy package contributed to the retreat of employment growth in South Africa, and thereby exacerbated poverty (Wessel, 2007). This could be attributed to its emphasis on budget deficit reduction, inflation targeting, and the resultant low consumer market.

\section{Poverty alleviation and wealth redistribution}

Although the South African economy continued to grow at an annual rate of about 5\% between 1994 and 2007 (Wessel, 2007), the situation changed more rapidly than expected when the economy retreated to $-1.8 \%$ growth in 2009. However, economic growth picked up at $2.8 \%$ towards the end of 2010 and it is expected to reach $3.9 \%$ in 2011 (EIU, 2010). Despite the 5\% growth recorded between 1994 and 2007, the real per capita GDP has been growing at an average annual rate of only $1.2 \%$, while the real wage rise was yet to catch up with the 1980 peak as at 2006 (Rodrik, 2007). This is an indication that attempts to redress poverty have not been successful. The proportion of the South African population living below US $\$ 1$ a day increased from $9.4 \%$ in 1995 to $10.5 \%$ in 2002 (Business Anti-Corruption, 2007).

On the issue of income/wealth redistribution, South Africa is one of the countries with the most skewed income distribution. Given a Gini index ${ }^{3}$ of $59.3 \%$, it is one of the most unequal societies in the world (Business Anti-Corruption, 2007). This explains prescient of the two economies in the country. About a third of the country earns less than R1, 500 per month, of which more than $50 \%$ are female (Du Plessis, Jooste and Strydom, 2005). While the GNP per capita of South Africa is more than US $\$ 3,000,30 \%$ of the population lives in abject poverty (Wessel, 2007). This furthers the negative argument against the GEAR, as a macroeconomic policy (Weeks, 1999; Magubane, 2002).

\section{Trade liberalisation}

GEAR identifies investments and exports promotion as the key drivers of growth (GEAR, Appendix 4). It intends to achieve this aim through trade liberalisation. Although trade liberalisation began in 1983 (Nattrass, 1996), GEAR was adopted to serve as the 'wrapping paper' to re-package the existing macroeconomic policies in such a way that policy 'credibility' would be achieved on the part of the government: it was intended to show government's commitment towards creating an investorfriendly environment (Gelb, 2006).

However, the trade liberalisation that resulted from GEAR appears to be unsuccessful since it has failed to facilitate a stable socio-economic environment, capable of improving the purchasing power and living standards of the people (Schimulow and Greyling, 1996; Michie and Padayachee 1998). More specifically, experience from the apartheid era has confirmed that promoting manufacturing exports without a corresponding increase in intermediate and capital goods would exert pressure on foreign reserves, thereby triggering capital account deficit (MERG, 1993; Van Seventer and Gibson, 1995; Gilroy, Gries and Naude, 2005). The current account deficit was exacerbated by the preparation to host the 2010 FIFA

\footnotetext{
${ }^{3}$ The degree of income distribution among individuals, mostly an approximate of income distribution among the $10 \%$ upper and bottom docile (named after the Italian statistician Cerrado Gini)
} 
world cup, when the deficit amounted to R16.9 billion (almost $8 \%$ of GDP) in the first quarter of 2008 (SARB, 2008).

Although exports promotion may possibly lead to economic growth (Rugumamu, 2005), there is no strong evidence to support this assumption (De Gregorio, 1996). Evidence from developed countries confirms that a higher percentage of production is geared towards domestic consumption (Roberts and Thoburn, 2004). More specifically, the USA and Japan's share of exports of their total output was only $8 \%$ and $10 \%$ on average between 1960 and 1994 respectively; a record that South Africa surpassed as the country's non-gold exports to GDP ratio was quoted at $21 \%$ over the same period ${ }^{4}$ (Adelzadeh, 1996: 71).

Despite the fact that capital flows (hot money) which the GEAR promoted as a macroeconomic policy is known for its susceptibility to crisis, in furthering financial instability in the host country (Magubane, 2002; Stiglitz and Charlton, 2005), the most disturbing aspect of GEAR's trade liberalisation has been import penetration. Evidence suggests that the hardest hit sectors were clothing (54\%), basic iron and steel (67\%) and paint (89\%) (Holden, 2001). In addition, profitability of the manufacturing sector has slumped on average, by $30 \%$ over time because of the stiff competition meted out to local manufacturers by advanced exporters (Rodrik, 2007). Undoubtedly, this has led to the demise of some local firms in these sectors, and the corresponding job losses have been far-reaching (Holden, 2001). As observed by Roberts and Thoburn (2004) employment has fallen in all the textile sub-sectors with spinning, weaving and finishing being the worst victims, where employment in 2001 was $45 \%$ less than it was in 1996. The situation became disturbing at the aftermath of the global economic crisis. Between 2008 and 2009, GDP growth dropped to -2.54 per cent and unemployment also entered into negative territory (a decline of -5.64 percent) (ICTSD, 2010:3). More specifically, more than 800000 jobs were lost between 2008 and 2009, and by early 2010 .

Besides the textile industry, the agriculture sector has also been hit by the liberalisation initiative institutionalised by GEAR. Statistics show that the contribution of agriculture to real economic growth has been decreasing over time (from $33 \%$ in 1951 , to less than $14 \%$ in 1985 , and to just $10 \%$ in 1991 (MERG, 1993: 171-172). This figure further slumped to $0.2,-0.1$, and $0.0 \%$ in 2002 , 2003, and 2004 respectively (Statistics SA, 2007); and progressed gently to $3.2 \%$ in 2007 (EIU, 2010). This may further support the argument against the appropriateness of GEAR's trade liberalisation, as subsidised agricultural produce from the West beats local producers in price competition.

More specifically, the penetration of foreign multinational enterprises (MNEs) in immature and less

\footnotetext{
${ }^{4}$ When the export of gold is included, the figure rises to more than $25 \%$ of GDP.
}

competitive sectors is presumably the main cause of continued under-development and exploitation of developing economies (Wilhelms and Witter, 1998; Seid, 2002; Aregbeshola and Palmer, 2007). It has been said that MNEs seek location specific advantages in the host countries without corresponding benefits for the host economies (UNCTAD, 1999; Kebonang, 2006). On a general note, liberalisation processes have spawned an 'imperial policy' of the conquest of capitalism over the rest of the world (Akindele, Gidado, and Olaopo, 2002). The benefits of trade liberalisation and economic openness advocated by the Washington consensus do not only benefit the West, but have entrenched their political and economic dominance as well. This is exemplified in Table 1, which illustrates exports statistics for North America, Europe and (South) Africa between 1948 and 2005.

In 1948, world exports were put at USD $\$ 59$ billion. North America (28.1\%) and Europe (35.1\%) accounted for more than $63 \%$ of the world's total. The European share of the world's total grew up until 2003, after which it declined slightly. The trend for North America was not as significant as that of Europe ${ }^{5}$, while African export has since been very disappointing.

Africa's figure fell from $7.3 \%$ of the world's total in 1948 to $2.4 \%$ in 2003 , before increasing to $3.1 \%$ in $2007^{6}$. The South African situation was not immune to these shortfalls. The country's exports fell from $2.0 \%$ in 1948 to $0.7 \%$ in 1993, and stabilised at $0.5 \%$ between 2003 and 2007. The recent balance of payment deficit on the national current account ${ }^{7}$ is a clear indication that GEAR has not achieved much in terms of its export promotion targets $^{8}$.

\section{FDI in the South African context}

The need for trade and trade-related activities has a historical basis. Trade and the cross-border movement of resources are as old as creation itself (Ball and McCulloch, 1988). In most cases, international trade has contributed to the shaping of international borders (Czinkota, Muffett and Ronkainen, 1994; Hill, 2011). Consequently, recent efforts by individuals and nation states, to participate in trade, may have been influenced by the documented benefits derivable from active trade participation. In the early days of trade, it was discovered that people's participation in any kind of trade (both national and international) was an unquestioned

\footnotetext{
${ }^{5}$ This may not be too surprising because most of American MNCs operate and produce abroad (UNCTAD, 2008).

${ }^{6}$ This may be attributed to the rapid rise in global demand for African mineral resources, essentially crude oil to power the sporadic Asian economic growth.

${ }^{7}$ The current account deficit was tamed at $4.6 \%$ in 2010 by the proceeds from hosting the soccer World Cup, but is expected to rise to $5.6 \%$ and $6.2 \%$ respectively in 2011 and 2012 (EIU, 2010).

${ }^{8}$ A successful export promotion should generate a positive balance of payment (China has one of the highest foreign reserves today, due to its successful export promotion strategy).
} 
Table 1. World merchandise exports by region and selected economy, 1948, 1953, 1963, 1973, 1983, 1993, 2003 and 2007.

\begin{tabular}{|c|c|c|c|c|c|c|c|c|}
\hline Variable & 1948 & 1953 & 1963 & 1973 & 1983 & 1993 & 2003 & 2007 \\
\hline & \multicolumn{8}{|c|}{ Value (Billion dollars) } \\
\hline \multirow[t]{2}{*}{ World } & 59 & 84 & 157 & 579 & 1838 & 3675 & 7375 & 13619 \\
\hline & \multicolumn{8}{|c|}{ Share (\%) } \\
\hline World & 100.0 & 100.0 & 100.0 & 100.0 & 100.0 & 100.0 & 100.0 & 100.0 \\
\hline North America & 28.1 & 24.8 & 19.9 & 17.3 & 16.8 & 18.0 & 15.8 & 13.6 \\
\hline United States & 21.7 & 18.8 & 14.9 & 12.3 & 11.2 & 12.6 & 9.8 & 8.5 \\
\hline Canada & 5.5 & 5.2 & 4.3 & 4.6 & 4.2 & 4.0 & 3.7 & 3.1 \\
\hline Mexico & 0.9 & 0.7 & 0.6 & 0.4 & 1.4 & 1.4 & 2.2 & 2.0 \\
\hline Europe $^{a}$ & 35.1 & 39.4 & 47.8 & 50.9 & 43.5 & 45.4 & 45.9 & 42.4 \\
\hline Germany $^{b}$ & 1.4 & 5.3 & 9.3 & 11.6 & 9.2 & 10.3 & 10.2 & 9.7 \\
\hline France & 3.4 & 4.8 & 5.2 & 6.3 & 5.2 & 6.0 & 5.3 & 4.1 \\
\hline Italy & 11.3 & 9.0 & 7.8 & 5.1 & 4.0 & 4.6 & 4.1 & 3.6 \\
\hline United Kingdom ${ }^{c}$ & 1.8 & 1.8 & 3.2 & 3.8 & 5.0 & 4.9 & 4.1 & 3.2 \\
\hline Africa & 7.3 & 6.5 & 5.7 & 4.8 & 4.5 & 2.5 & 2.4 & 3.1 \\
\hline South Africa $^{d}$ & 2.0 & 1.6 & 1.5 & 1.0 & 1.0 & 0.7 & 0.5 & 0.5 \\
\hline GATT/WTO Members ${ }^{\mathrm{e}}$ & 62.8 & 69.6 & 75.0 & 84.1 & 78.4 & 89.4 & 94.3 & 94.1 \\
\hline
\end{tabular}

Source: Adapted from the World Trade Organisation (WTO 2010).

a. Figures refer to the EEC(6) in 1963, EC(9) in 1973, EC(10) in 1983, EU(12) in 1993, and EU(25) in 2003 and 2006.

b. Figures refer to the Fed. Rep. of Germany from 1948 through 1983.

c. Figures are significantly affected by i) changes in the country composition of the region and major adjustment in trade conversion factors between 1983 and 1993; and ii) including the mutual trade flows of the Baltic States and the CIS between 1993 and 2003.

d. Beginning with 1998, figures refer to South Africa only and no longer to the Southern African Customs Union. e. Membership as of the year stated.

Between 1973 and 1983 and between 1993 and 2003 export shares were significantly influenced by oil price developments

necessity as it augmented (and still augments) economic growth and development (Ball and McCulloch, 1988), a situation that is more relevant now, than ever (Hill, 2011). Opportunities provided by trade through the exchange of goods and services, which includes the availability of a variety of merchandise and services, contribute to increased per capita GDP for participating countries (Ouattara, 1997; Correa and Kumar, 2003; Akinkugbe, 2005). This invariably improves both the living standards and the quality of lives of the affected people (Köhler, 2003; Hill, 2011).

To derive even more benefit from trade, economies were encouraged to liberalise and embrace foreign investments (Akindele, Gidado, and Olaopo, 2002). The unprecedented efforts geared towards trade liberalisation and openness of economies to international competition has resulted in increasing both the stock and the flow of FDI in recent time (UN, 2007). To enhance trade, the global regulatory frameworks were developed to lessen the hindrances that hitherto frustrated international flow of capital (FDI and FPI) (Narula and Lall, 2006; Hill, 2011). This has been achieved through the advent of regulatory institutions established during World War II to avoid a repeat of the global economic depression of the 1930s, and to prevent the rise of fascist regimes like that of Germany in the first part of the $20^{\text {th }}$ century, that led to the Second World War (Kindleberger, 1989; Mishkin, 2006). This process has also been facilitated by the global economic institutions like the WTO, the IMF and the World Bank (Salil, 1995). The influence of the United Nations in this regard has also been significant.

In essence, the ability of any nation to generate growth through FDI depends on the organisational settings, quality of labour (skills), technological capability of the host nation's firms and their competitiveness - the national absorptive capacities or social capabilities (Asheghian, 2004; Shafaeddin, 2005). This suggests that a lack of or low absorptive capabilities may jeopardise the potential economic gains derivable from FDI (Basu and Weil, 1998).

The relevance of FDI to the South African economy culminated in the policy adjustment of 1993. Prior to its political emancipation, South Africa adopted an explicit industrial policy epitomised by Import Substitution Industrialisation (ISI) from the mid-1920s up to the period after World War II as a way to circumvent the negative effects of international sanctions meted out to the apartheid regime (Moritz, 1994; Nattrass and Terreblanche, 1990; 
Lewis, Reed and Teljeur, 2004). The ISI strategy recorded initial success as the economy transformed from the production of consumer goods to that of capital and intermediate goods. As a result of overcapitalisation caused by the importation of machines and foreign capital (intermediation), there was a balance of trade deficit that amounted to some 25\% of GDP in 1925 (Moritz, 1994). It was not surprising that the government adopted export promotion in 1990, supported with an incentive scheme (the General Export Incentive Scheme) to boost exports (Lewis, Reed and Teljeur, 2004).

\section{METHODOLOGY}

The focus of this research was to test the relationship between FD inflows to South Africa and the effects of macroeconomic policies that regulate foreign investment in the country. A test of exact significance level of the interaction between the dependent (FDI inflows) and the independent (policy framework) was applied to examine the extent to which the trend of FDI inflow is policy dependent.

The research postulated that the timing and application of GEAR as a macroeconomic policy were not only erroneous, but also inappropriate. Subsequent to the literature review, an empirical survey was conducted using two sets of structured and selfadministered questionnaires. The empirical survey (as explained in the following paragraphs) was considered necessary to garner the practical effects of the macroeconomic policies on FDI (greenfield) ${ }^{9}$ inflow and its retention in South Africa.

\section{Research hypotheses}

This research tested the opinions of both the policy makers and the foreign investors in South Africa on the role played by selected macroeconomic initiatives to attract FDI. Policy-informed FDI determinants are proxied by explanatory variables as used in Chakrabarti (2001) and Asiedu (2002). Although, this research adopted a different methodology to Chakrabarti and Asiedu, the explanatory variables measured are largely convergent. While various authors arrive at different conclusions on FDI determinants, there is a convergence that factors that evaluate capital productivity gains are positively significant in determining a country's attractiveness to inflow of FDI. The variation in results have been attributed to the different research methodologies adopted by authors (Blonigen and Wang, 2004; Kolstad and Villanger, 2008).

\section{Population and sampling}

The population groups that received attention in this study were divided into two categories: foreign investors and policy makers. Relevant officials at the provincial and national levels represented the policy makers' group. A snowball approach was used to identify the most senior officials, and confidentiality of information was promised. Relevant information about the investors, such as the business names, the contact addresses, the contact persons (mainly the top management level officials), and sector of participation, were obtained from the Commercial Intelligence Service (CSI), a division of the Business Monitor International 2007 edition that centres on foreign enterprises in South Africa. The

\footnotetext{
${ }^{9}$ Greenfield investment is chosen based on its comparative advantage over $\mathrm{M}$ \& A (UNCTAD, 2008).
}

researcher adopted a random sampling method to ensure that every member in the population sample would have an equal probability of representation. No sector/industry was excluded from this survey. In all, 68 research questionnaires were distributed among the targeted population, out of which 30 were returned completed after a series of reminders and some persuasion.

\section{RESULTS AND ANALYSES}

In analysing the data, significance is established if the probability associated with the test of the statistics is less than 0.05 ( $5 \%$ level of significance), or less than 0.01 ( $1 \%$ level of significance) or less than $0.001(0.1 \%$ level of significance). This is indicated as ' $\mathrm{Pr}>$ chi-sq' in the analysis. The frequency tables used for the preliminary analysis generally indicate that the most favoured type of FDI to South Africa is the greenfield type. This supports the assertion that greenfield FDI benefits the host countries more, essentially because it creates jobs, improves the host economy's foreign earnings, improves the quality and standard of living of the people, and contributes to the productivity and growth of local enterprises through spillover effects/externalities (Dunning, 1988; Blomstrom and Sjoholm, 1998; Elmawazini, Saadi and Ngouhouo, 2005). To this effect, the test of hypotheses was based on inflow of greenfield FDI. This analysis is contained in Table 2.

Table 2 shows that respondents generally felt that the Empowerment Charter should be reviewed. Twenty out of the 26 respondents felt strongly about the need for the government to reform the policy if the government is committed to attracting inflow greenfield FDI. A stronger sentiment (24 out of 25) was expressed on the issue of interest rates, which has been criticised as being one of the globally highest up until 2009. Labour policies were tamed with some lighter acceptance, but strongly in the negative territory; the same could be said of income redistribution/poverty prevalence. The statistical connotation of this analysis is contained in Table 3.

From Table 3 , the probability associated with the Pearson's Exact test for the policies interrogated is greater than 0.05 - it is indicated as 0.6460 (it is given as ' $\mathrm{Pr}<=\mathrm{Chi} \mathrm{Sq}$ ). The Chi-Squared test (not presented here) $=3.8849$ and the probability associated with the statistic is 0.6460 , thus indicating non-significance. Significance in this instance would have indicated that investors and policy makers did not respond in a similar way to all the options - that they 'preferred' some policy options to others (as shown in Table 2). This could not be established in this instance. This indicates that the respondents generally perceived the need to reform the policies examined. By implication, this confirms that all the listed policies need to be reformed to make South Africa more attractive for inflow of greenfield FDI.

The research also probed the impact of 'other' issues/ forces on the attractiveness of South Africa to inflow greenfield FDI. Some measurable indicators of possible hindrances to inflow FDI were examined. The results are 
Table 2. Favourability of selected measurable indicators of GEAR to inflow FDI.

\begin{tabular}{|c|c|c|c|c|}
\hline \multirow{2}{*}{ Reform I } & \multicolumn{3}{|c|}{ Favourite policy-reform rating } & \multirow{2}{*}{ Total } \\
\hline & Negative & Positive + & Positive ++ & \\
\hline \multicolumn{5}{|c|}{ Empowerment charters } \\
\hline Frequency & 6 & 11 & 9 & 26 \\
\hline Percent & 5.88 & 10.78 & 8.82 & 25.49 \\
\hline Row per cent & 23.08 & 42.31 & 34.62 & \\
\hline \multicolumn{5}{|c|}{ High interest rate } \\
\hline Frequency & 2 & 13 & 11 & 26 \\
\hline Percent & 1.96 & 12.75 & 10.78 & 25.49 \\
\hline Row per cent & 7.69 & 50.00 & 42.31 & \\
\hline \multicolumn{5}{|c|}{ Labour policies } \\
\hline Frequency & 5 & 9 & 10 & 24 \\
\hline Percent & 4.90 & 8.82 & 9.80 & 23.53 \\
\hline Row per cent & 20.83 & 37.50 & 41.67 & \\
\hline \multicolumn{5}{|c|}{ Income redistribution } \\
\hline Frequency & 7 & 11 & 8 & 26 \\
\hline Percent & 6.86 & 10.78 & 7.84 & 25.49 \\
\hline Row per cent & 26.92 & 42.31 & 30.77 & \\
\hline \multirow[t]{2}{*}{ Total } & 20 & 44 & 38 & 102 \\
\hline & 19.61 & 43.14 & 37.25 & 100.00 \\
\hline
\end{tabular}

Table 3. Monte Carlo estimate for the exact test.

\begin{tabular}{lc}
\hline Pr >= Chi Sq. & 0.6460 \\
99\% Lower Conf Limit & 0.6337 \\
99\% Upper Conf Limit & 0.6583 \\
Number of Samples & 10000 \\
Initial Seed & 1943940033 \\
\hline
\end{tabular}

presented in Tables 4 and 5 .

Table 4 indicates that $88 \%$ of the respondents regarded political instability as a possible hindrance to inflow greenfield FDI to South Africa. Most of the respondents that were reticent in acknowledging the negative impact of political instability were largely policy makers. Lack of skilled labour was identified as one of the major hindrances to inflow greenfield FDI to South Africa by $85 \%$ of the respondents, and a similar percentage (81\%) regarded small market size as a possible hindrance. All the respondents (both investors and policy makers) admitted that crime is a strong deterrent to inflow greenfield FDI to South Africa. The statistical nuance of this analysis is presented in Table 5 .

Table 5 indicates that the probability associated with the Pearson's Exact test for the factors/issues that hinder inflow FDI to South Africa is less than 0.05. It is indicated as 0.0027 (it is indicated as ' $\operatorname{Pr}<=$ Chi Sq' in the analysis, where Chi-square $=19.3652$ and the probability associated with the statistic is 0.0027 ), thus indicating significance.

A critical evaluation of the values of the cell Chi-square in the two tables (for first and second hypotheses) indicates that the cell Chi-square values for each variable tested in Tables 4 and 5 are higher than those in Tables 2 and 3 . This indicates that although policy reforms will improve South Africa's attractiveness to FDI inflow (as contained in Tables 2 and 3), the impact of other tested variables (presented in Tables 4 and 5) are more significant.

More specifically, the cell Chi-values 5.4218 for crime (with a frequency of 22 for the positive++ category) and 3.3645 , also for crime in the cell-chi-square contribution (with a frequency of zero for the negative category), indicate that respondents viewed crime in a significantly different way to the other FDI issues. They generally 
Table 4. Obstacles to inflow FDI to South Africa.

\begin{tabular}{lcccc}
\hline Variable & Negative & Positive & Positive ++ & Total \\
\hline Political instability & & & & \\
Frequency & 3 & 13 & 9 & 25 \\
Cell Chi-Square & 0.0137 & 0.3711 & 0.4375 & \\
Percent & 2.80 & 12.15 & 8.41 & 23.36 \\
Row Pct & 12.00 & 52.00 & 36.00 & \\
& & & & \\
Skilled labour shortage & & & 12 & 26 \\
Frequency & 4 & 10 & 0.0097 & \\
Cell Chi-Square & 0.4031 & 0.1767 & 11.21 & 24.30 \\
Percent & 3.74 & 9.35 & 46.15 & \\
Row Pct & 15.38 & 38.46 & & \\
& & & & \\
Small market size & & 16 & 5 & 26 \\
Frequency & 5 & 1.8363 & 3.807 & \\
Cell Chi-Square & 1.4896 & 14.95 & 4.67 & 24.30 \\
Percent & 4.67 & 61.54 & 19.23 & \\
Row Pct & 19.23 & & & \\
& & 8 & & \\
Crime & & 2.0343 & 5.4218 & \\
Frequency & 0 & 7.48 & 20.56 & 28.04 \\
Cell Chi-Square & 3.3645 & 26.67 & 73.33 & \\
Percent & 0.00 & 47 & 48 & 107 \\
Row Pct & 0.00 & 43.93 & 44.86 & 100.00 \\
Total & 12 & & \\
& 11.21 & & & \\
\hline
\end{tabular}

Table 5. Monte Carlo estimate for the exact test.

\begin{tabular}{lc}
\hline Pr $>=$ Chi Sq. & 0.0027 \\
$99 \%$ Lower Conf Limit & 0.0014 \\
$99 \%$ Upper Conf Limit & 0.0040 \\
Number of Samples & 10000 \\
Initial Seed & 458046001 \\
\hline
\end{tabular}

regarded crime as being a very important variable that hinders the attractiveness of South Africa to inflow greenfield FDI.

To support this point, it must be pointed out that South Africa spends above global standard on the police service, courts and prisons. Specifically, this amounted to $3 \%$ of GDP in 2004 , or an average of USD $\$ 130$ per person on criminal justice, as compared to the world average of $1 \%$ or USD $\$ 66$ per person) (EIU, 2005). In 2007, the aggregated cost of crime in South Africa amounted to US\$22.1 billion, constituting almost $8 \%$ of GDP (Alda and Ceusta, 2010). These authors also found that institutional cost of crime constitute the highest expenditure on crime management in the country. This is a clear indication that crime is indeed a real problem in the country. The Global Competitiveness Report (2010 to
2011) ranks South Africa 137th out of 139 countries on the business costs of crime and violence, and 104th on the unreliability of police services to protect victims from crime.

\section{Conclusion}

This article examines the relationship between the macroeconomic policy initiatives and the attractiveness of South Africa to long-term capital inflow. It is clear that investment behaviour has been less impressive since the political emancipation in 1994, owing to a series of policy misjudgements - essentially the macroeconomic policies. The research on which this paper was based verifies that crime, small market size, socio-political instability, and 
skilled labour shortages in South Africa are perceived by policy makers and foreign investors who participated in this study as being the major deterrents to inflow of greenfield FDI into the country. From the preceding discourse it appears as if the lingering socio-economic problems are precipitated by the measurable indicators of the macroeconomic policy, thereby strengthening the unpopularity of GEAR as a macroeconomic strategy. One could acknowledge the efficiency of GEAR in its appeal to capital, and the corresponding inflow of portfolio investment. While the capital inflow has helped to stabilise the capital market by advancing the capitalist agenda, the opportunity cost on the part of a long-lasting capital/asset inflow has been missed.

This study has shown that efforts are needed to improve the socio-economic conditions in South Africa, as a measure to create an investor-friendly environment that is capable of attracting greenfield FDI to the country. It is suggested that policy be rethought to ameliorate the inherent shortcomings in GEAR as a policy framework, especially with regard to poverty alleviation. Although the Accelerated Growth Initiatives for South Africa (ASGISA, 2006) strategy has proved its balancing essentiality to GEAR, over-reliance on the credibility of this strategy to woo investors may be risky, especially given its brief as a complement to GEAR and not as a policy intervention on its own.

Overall, it is suggested that the government and other stakeholders shift their focus to the possible use of an alternative strategy as an intervention mechanism to improve the labour-intensive (manufacturing) export base of the economy, as a way to reduce unemployment, thereby alleviating poverty. A well-guided wealth redistribution mechanism that is different from the current controversial Broad-Based Black Economic Empowerment (BBBEE) should be devised. It is observed that a well-guided, truly redistributive mechanism will pacify the most negatively affected constituent, and create an enabling environment that is capable of enlarging the market size, ensuring socio-economic peacefulness, thereby attracting inflow of greenfield FDI.

\section{REFERENCES}

Adelzadeh A (1996). From The RDP to GEAR: The Gradual Embracing of Neo-Liberalism in Economic Policy. Transformation, 31: 66-95.

Akindele ST, Gidado TO, Olaopo OR (2002). Globalisation, its implications and consequences for Africa. Globalisation. Available: http://globalisation.icaap.org/content/v2.1/01_akindele_etal.html [accessed 08 June 2010].

Akinkugbe O (2005). A Two-part Econometric Analysis of Foreign Direct Investment Flows to Africa. Netherlands: Kluwer Law International.

Alda E, Cuesta J (2010). A Comprehensive Estimation of Costs of Crime in South Africa and Its Implications for Effective Policy Making. Journal of International Development. Available online at: http://www.securitytransformation.org/images/documentos/779_Costs South_Africa.pdf.

Aregbeshola RA, Palmer PN (2007). The Phantasm of Globalised Africa: Discerning the Imagery - A South African Perspective. Lex et Scientia, 14: 21-39.
ASGISA - The Accelerated Growth Initiatives for South Africa (2006). Available online

http://www.info.gov.za/speeches/briefings/asgibackground.pdf.

Asheghian P (2004). Determinants of Economic Growth in the United States: The Role of Foreign Direct Investment. Int. Trade J., 18(1): 63-83.

Asiedu E (2002). On the Determinant of Foreign Direct Investment to Developing Countries: is Africa different? World Dev., 30(1): 107-119.

Ball DA, McCulloch WH Jr (1988). International Business. Introduction and essentials. $3^{\text {rd }}$ edition. Texas: Business Publications Inc.

Barro R (1995). Inflation and Economic Growth. London. Bank England Econ. Bull., pp. 1-11.

Barro R (1996). Determinants of Economic Growth: A Cross-Country Empirical Study. Cambridge. NBER Working Paper Series (5698).

Basu S, Weil DN (1998). Appropriate technology and growth. Q. J. Econs., 113(4): 1025-1054.

Blomstrom M, Sjoholm F (1998). Technology Transfer and Spillovers: Does Local Participation with Multinationals Matter? Eur. Econ. Rev., 43(4-6): 915-923.

Blonigen BA, Wang M (2004). Inappropriate pooling of wealthy and poor countries in empirical FDI studies. NBER Working Paper Series 10378.

Business Anti-Corruption Portal: South Africa Country Profile (2007). Available: corruption.com/normal.asp?pageid=98.

Chakrabarti A (2001). The Determinants of Foreign Direct Investment: Sensitivity Analyses of Cross-Country Regressions. KYKLOS, 54(1): 89-114.

Correa CM, Kumar N (2003). Protecting Foreign Investment: Implications of a WTO regime and policy options. United Kingdom: Zed Books Ltd.

Czinkota MR, Ronkainen IA, Moffett MH (1994). International Business. $3^{\text {rd }}$ edition. Fort Worth: The Dryden Press.

De Gregorio J (1996). Inflation, Growth and Central Banks: Theory and Evidence. Policy Research Working Paper. Washington D.C. The World Bank

De Vroey M (1984). Inflation: a non-monetarist monetary interpretation. Camb. J. Econs., 8(4): 381-399.

Du Plessis PJ, Jooste CJ, Strydom JW (2005). Applied Strategic Marketing. $2^{\text {nd }}$ edition. Sandown: Heinemann.

Dunning JH (1988). Multinationals, technology and competitiveness. London: Unwin Hyman.

Economist Intelligent Unit (EIU) (2005). Boosting Foreign Investment. Business Africa. The Economist Int. Unit Ltd.

Economist Intelligence Unit (EIU) (2010). Country Focus - South Africa. The Economist Int Unit Ltd.

Elmawazini K, Saadi S, Ngouhouo I (2005). Does FDI Imply Productivity Growth for the Host Economy? J. Am. Acad. Bus., 1(2): 85-90.

Fine B (1995). Privatisation and the RDP: A Critical Assessment. Transform., 27(1):1-23.

Fine B, Rustomjee Z (1996). South Africa's Political Economy: From Minerals-Energy Complex to Industrialisation? London: Hurst.

Frank AG (1969). The Development of Underdevelopment. Monthly Rev., 18(4).

Gelb S (2006). The RDP, GEAR and all that: reflections ten years later. Transform., 62(1): 1-8.

Gilroy MB, Gries T, Naude WA (2005). Multinational Enterprises, Foreign Direct Investment and Growth in Africa: South African Perspectives. New York: Physica-Verlag.

Hill CWL (2011). International Business. Competing in the global marketplace. $8^{\text {th }}$ edition. New York: McGraw-Hill Irwin.

Hirsch A (1993). Trading up: towards a trade policy for industrial growth in South Africa. ISPDP Research Unit. Cape Town: University of Cape Town.

Holden M (2001). Trade policy in a liberalising economy. J Int. Dev., 13(6): 711-723

International Centre for Trade and Sustainable Development (ICTSD) (2010). A Comparative Assessment of How Trade Liberalisation and the Economic Crisis have impacted India and

South Africa. Information Note Number 13. December 2010. Available online: http://ictsd.org/downloads/2010/12/information-note_indiaand-south-africa.pdf. 
Javier A, Ignacio H (1997). Does Inflation Harm Economic Growth? Evidence for the OECD. Cambridge. NBER Working Paper Series, 6062.

Kapstein EB (1999). A Global Third Way: Social Justice and the World Economy. World Pol. J., 15(4): 23-35.

Kebonang Z (2006). NEPAD: Drawing lessons from theories of foreign direct investment. J. Econs. Bus., 5(2), 255-272.

Köhler H (2003). The Challenges of Globalisation and the Role of the IMF. Available: http://www.imf.org/external/np/speeches/2003/051503.htm [accessed 04 June 2010].

Kindleberger CP (1989). Commercial Policy between the War. In Mathias, P. and Pollard S. (eds). The Cambridge Economic History of Europe, $8^{\text {th }}$ editions. Cambridge: Cambridge University Press.

Kolstad I, Villanger E (2008). Determinants of Foreign Direct Investment in Services. Eur. J. Pol. Econ., 24(2): 518-533.

Lewis D, Reed K, Teljeur E (2004). South Africa: Economic PolicyMaking and Implementation in Africa: A study of Strategic Trade and Selective Industrial Policies. In Soludo C, Ogbu O, Change H (eds) (2004). The politics of Trade and Industrial Policy in Africa: Forced consensus? New Jersey: Africa World Press, Inc.

Magubane Z (2002). Globalisation and the South Africa transformation: the impact on social policy. Pro. Museum, 49(4): 89-110.

MERG (1993). Making Democracy Work. A Framework for Macroeconomic Policy in South Africa. Cape Town: Centre for Development Studies and Uppsala: Scandinavian Institute of African Studies.

Michie J, Padayachee V (1998). Three years after apartheid: growth, employment and redistribution? Camb. J. Econs., 22(5): 623-635.

Mishkin F (2006). Promoting the next great globalisation. Financial Times, 10:11

Moritz L (1994). Trade and Industrial Policies in the New South Africa. Sweden: Motala Grafiska.

Nattrass N (1994). Politics and Economics in ANC Economic Policy. Afr. Aff. 93(372): 343-359

Nattrass N (1996). Gambling On Investment: Competing Economic Strategies in South Africa. Transformation, 31: 25-42.

Nattrass N (2001). High Productivity Now: a critical review of South Africa's growth strategy. Transformation, 45: 1-24.

Nattrass N, Terreblanche S (1990). A periodisation of the political Economy from 1910-1990. In Nattrass N, Ardington E (1990). The Political Economy of South Africa. Cape Town: Oxford University Press.

Narula R, Lall S (2006). Understanding FDI-Assisted Economic Development. Abingdon: Routledge.

Ouattara AD (1997). The challenges of globalisation for Africa. IMF (speech).

Available: http://www.imf.org/exeternal/np/speeches/1997/052197.htm.

Phillips P (2000). Seattle Awakens Working People to the Danger of Globalisation. Soc. Policy, Spring: 34-40.

Rich B (1994). Mortgaging the Earth: The World Bank, Environmental Impoverishment, and the Crisis of Development. In The World Bank. 41. Boston: Beacon Press.

Roberts S, Thoburn JT (2004). Globalisation and the South African textiles industry: impacts on firms and workers. J. Int. Dev. 16(1): 125-139.

Rodrik D (2007). The Financial Mail. 01 June.

Rugumamu SM (2005). Globalisation Demystified: Africa's possible development futures. Dar Es Salaam. Dar Es Salaam University Press.

Salil S (1995). From GATT to WTO: The Institutionalisation of World Trade. Harv. Int. Rev., 17(2): 46-67.
Schimulow D, Greyling L (1996). Monetary Policy in the New South Africa: Economic and Political Constraints. SAJE, 64(3): 158-167.

Seid S (2002). Global Regulation of Foreign Direct Investment. England: Ashgate Publishers.

Shafaeddin M (2005). Trade Policy at the crossroads - the recent experience of the developing countries. New York: Palgrave Macmillan.

Smith J, Moran TM (2000). WTO 101: Myths About the World Trade Organisation. Dissent, 1: 66-70.

Standing G, Sender J, Weeks J (1996). Restructuring the Labour Market: The South African Challenge. Geneva: ILO.

Statistics South Africa (Statistics SA) (2009). Gross Domestic Product. Annual Estimates for $1993-2008$ ( $1^{\text {st }}$ quarter) Available: www.statssa.gov.za.

Stiglitz JE (2002). Globalisation and its Discontents. New York: WW Norton.

Stiglitz JE, Charlton A (2005). Fair Trade for All. New York: Oxford press.

The GEAR - The growth, Employment and Redistribution (GEAR): A Macroeconomic Strategy (1996). Available online at: http://www.info.gov.za/otherdocs/1996/gear.pdf.

The RDP - The Reconstruction and Development Programme (RDP): A Policy Framework (1994). Available online at: http://www.polity.org.za/html/govdocs/rdp/rdpall.html.

The South African Reserve Bank (SARB) (2008). Monetary Policy Review. Available: http://www.reservebank.co.za.

United Nations (2007). World Economic Situation and Prospects. New York and Geneva: The United Nations.

United Nations Conference on Trade and Development (UNCTAD) (2008). Foreign Direct Investment Reaches New Record in 2007. Available:

http://www.unctad.org/Templates/Webflyer.asp?doclD=9439\&intlteml $\mathrm{D}=2068$ \&lang $=1$.

The United Nations Conference on Trade and Development (UNCTAD) 1999. Foreign Portfolio Investment (FPI) and Foreign Direct Investment (FDI): Characteristics, Similarities, Complementarities and Differences, Policy Implications and Development Impact. Geneva. The United Nations.

The Global Competitiveness Report 2010-2011 (2010). World Economic Forum, Geneva, Switzerland.

Van Seventer D, Gibson B (1995). Towards a Growth Strategy for the South African Economy. Johannesburg: Development Bank of Southern Africa.

World Trade Organisation (WTO) (2010). World Trade Statistics. Available: http:// www.wto.org/english/res_e/statis_e/ its2010_e/ section1 e/i21.xls.

Wallach L, Woodall P (2004). Whose Trade Organisation? New York: The New Press.

Weeks J (1999). Stuck in low GEAR? Macroeconomic policy in South Africa, 1996-98. J. Econ., 23: 795-811.

Wessel D (2007). Capital: Globalisation brings South Africa Gains and Pains. Wall Street J. June 21: A.2

Wilhelms SKS, Witter MSD (1998). Foreign Direct Investment and its Determinants in Emerging Economies. Available online at: http://www.eagerproject.com/discussion9.shtml. 
Reproduced with permission of the copyright owner. Further reproduction prohibited without permission. 